ISSN 1392-3196 / e-ISSN 2335-8947

Zemdirbyste-Agriculture, vol. 101, No. 1 (2014), p. 57-66

DOI 10.13080/z-a.2014.101.008

\title{
Potato pulp as a composting substrate
}

\author{
Olga MUTER ${ }^{1}$, Aivars POGULIS ${ }^{2}$, Mara GRUBE ${ }^{1}$, Marita GAVARE ${ }^{1}$, Andrejs BERZINS ${ }^{1}$, \\ Silvija STRIKAUSKA ${ }^{3}$, Uldis HANSONS ${ }^{2}$, Andrejs HANSONS ${ }^{2}$ \\ ${ }^{1}$ Institute of Microbiology and Biotechnology, University of Latvia \\ 4 Kronvalda, Riga, Latvia \\ E-mail: olga.muter@inbox.lv \\ ${ }^{2}$ EKOTRI Ltd. \\ 4 Ezera, Ungurpils, Aloja district, Latvia \\ ${ }^{3}$ Latvia University of Agriculture \\ 2 Liela, Jelgava, Latvia
}

\begin{abstract}
Potato pulp is a waste, which is produced in considerable quantities by starch manufacturing industry. Addition of pulp fibre residue to soil results in beneficial effects on soil physical and biochemical properties. In this study, organic potato pulp was mixed with organic grass in three concentrations (75:25 (A), 50:50 (B) and 25:75 (C) \% $\mathrm{w} / \mathrm{w}$ ) with the aim of comparing the dynamics of the composting process during a 30-day period. A mini-field experiment was conducted in $0.7 \mathrm{~m}^{3}$ windrows which were left without covering and additional mixing during composting process, except sampling procedure. During 30-days' experiment the C:N ratio decreased from $25 \div 30$ to $13 \div 17$ indicating the active conversion of organic matter in windrows with three different combinations of the substrate. An increase of grass concentration led to an increase of the temperature in the windrow at the thermophilic phase of the process. This effect can be explained by higher porosity of the composting substrate containing $75 \%$ grass and $25 \%(\mathrm{w} / \mathrm{w})$ potato pulp. Fourier transform infrared (FT-IR) spectra of compost water extracts indicated the heterogeneity of compost. The water content in two windrows was $59 \div 75 \%$ and $81 \div 86 \%$, respectively, thus indicating considerable differences in the dynamics of physico-chemical and microbiological processes. The order of earthworms' preference for compost samples can be listed as follows: $\mathrm{A}<\mathrm{C}<\mathrm{B}$. Therefore, the ratio potato pulp:grass as 1:1 could be considered as the most optimal under the tested conditions.
\end{abstract}

Key words: composting, earthworm avoidance test, eco-toxicity, Fourier transform infrared spectroscopy, microbial enzyme activity, potato pulp.

\section{Introduction}

One of the most versatile and remunerative techniques for handling biodegradable solid wastes is composting, which has the benefit-cost ratio higher than 1 at all scales of operation. Composting process has the advantage of reducing mass, volume, pathogenic microorganisms and production of fertilizers. All kinds of organic residues amenable to the enzymatic activities of the microorganisms can be converted into compost if suitable conditions for biodegradation are provided. A large variety of such wastes of plant, animal, and synthetic origins can be gainfully composted (Gajalakshmi, Abbasi, 2008; Orrico et al., 2012).

Potato pulp is a waste, which is produced in considerable quantities by starch manufacturing industry. Its composition strongly depends on the starch production technology. Apart from the non-starch fraction which comprises cellulose, hemicellulose and pectins, the so called "unwashed" starch in potato pulp is in significant amounts (Lesiecki et al., 2012). The use of potato by-products in livestock diets had been examined for lactating dairy cows, beef cattle and sheep (Aibibula et al., 2007). Composition of potato pulp makes it a potential and attractive raw material for the production of the second generation bioethanol (Lesiecki et al., 2012). Besides, potato pulp can be converted to palatable foodstuff by microbial fermentation (Abe et al., 2004). Pulp fibre residue addition may restore the quality of soils. Application of the both raw and composted potato pulp to the potato fields before planting resulted in a great increase in soil organic matter content, the $\mathrm{C}: \mathrm{N}$ ratio, macroaggregation, carbon mineralization, microbial biomass carbon and enzyme activities. The beneficial effects on soil physical and biochemical properties were detected even after three years of continuous cropping (Gagnon et al., 2001).

Nevertheless, composting of potato pulp with addition of another biodegradable substrate is considered to be more efficient than potato pulp alone. 
Thus, composts made from municipal sewage sludge and potato pulp contained more organic matter and nutrients for plants than composts prepared only from potato pulp independently of the additions (straw, saw dust) used (Krzywy et al., 2004). Besides, production of high quality promoters without any agrochemicals is a holistic way of organic farming (Densilin et al., 2011). To produce a valuable fertilizer via composting for its further application on organic fields, the composting process is limited by raw materials obtained by organic management practice.

In this study, organic potato pulp was mixed with organic grass in three concentrations with the aim of comparing the dynamics of the composting process during a 30-day mini-field experiment in windrows. The mini-filed experiment is expected to indicate to the most optimum composition of raw material for further establishing the full-scale experiment under given climatic conditions.

\section{Materials and methods}

Experimental design and mini-field trial. Compost facility. EKOTRI Ltd. conducted composting at their compost factory facility located in Aloja district, Latvia.

Feedstock preparation for composting. Potapo pulp was obtained from the processing of organic starch at Aloja-Starkelsen Ltd. Organic grass was collected during 2011 and stored on the field.

Experimental design. For mini-field experiment potato (Solanum tuberosum L.) pulp and grass were mixed in three proportions by weight, i.e. $3: 1,1: 1$ and $1: 3$, respectively. Each set was established as a windrow with a volume $\sim 0.7 \mathrm{~m}^{3}$, in duplicate. Duration of the experiment was one month, from 19 July 2012 till 18 August 2012. Windrows were left without covering and additional mixing during composting process, except sampling procedure. Sampling was done at day 5, 10, 15 and 30 of the experiment. Samples were immediately frozen until testing.

Climatic conditions. Precipitation in July and August was 86 and $107 \mathrm{~mm}$, respectively. Average temperature in July and August was $18^{\circ} \mathrm{C}$ and $15^{\circ} \mathrm{C}$, respectively. During this experiment the highest and lowest temperatures were $32^{\circ} \mathrm{C}$ and $7^{\circ} \mathrm{C}$, respectively (http://www.accuweather.com).

Analytical methods. Evolution of volatile compounds produced in windrows during the experiment was measured on-site using bellows hand pump Dräger Accuro ${ }^{\circledR}$ in conjunction with appropriate detector tubes ("Drägerwerk", Germany). Temperature was measured in the centre of the windrow. Dry weight was determined by drying of compost samples at $105^{\circ} \mathrm{C}$ until constant weight. Ash content was determined according to ISO 5984: 2002/Cor 1:2005, potassium was determined with AAS according to LVS EN ISO 6869:2002, phosphorous was determined according to ISO 6491:1998. Total nitrogen content was determined according to ISO 5983-2:2005 using an automatic system Auto Kjeldahl Unit K-370
("Büchi”, Switzerland). Total carbon and sulphur was measured with an automatic analyzer CS Eltra ("Eltra", Germany). $\mathrm{pH}$ value and redox potential were measured in water (1:5) with a pH-meter Hanna pH213 ("Hanna Instruments", USA). Substrate-induced respiration rate of compost samples was measured in $100 \mathrm{ml}$ incubation vessel containing $25 \mathrm{~g}$ wet compost. Prior to conducting the respiration tests, the fresh compost samples were pre-incubated at ambient temperature for $48 \mathrm{~h}$ in order to restore mesophillic microbial activity. Each sample was mixed again thoroughly after pre-incubation. $5 \mathrm{ml}$ of $1 \%$ glucose was added. Carbon dioxide produced during $6 \mathrm{~h}$ incubation was collected in a glass vial with $5 \mathrm{ml}$ of $0.05 \mathrm{M} \mathrm{NaOH}$. Incubation included a blank, consisting of a sealed vessel containing a $\mathrm{NaOH}$ trap, but no compost. Measurement of $\mathrm{CO}_{2}$ dissolved in $\mathrm{NaOH}$ was performed after $6 \mathrm{~h}$ incubation by titration of $\mathrm{NaOH}$ with $0.05 \mathrm{M}$ $\mathrm{HCl}$. Fluorescein diacetate (FDA) hydrolysis activity was measured in compost water extracts ( $8 \mathrm{~g}$ wet compost in $32 \mathrm{ml}$ distilled water) according to Chen et al. (1988) with some modifications. $100 \mu \mathrm{l}$ of water extract, which was previously diluted 100 times, was added to $500 \mu \mathrm{l}$ of $0.06 \mathrm{M}$ phosphate buffer $\mathrm{pH} 7.6$ which contained $40 \mu \mathrm{g}$ FDA in $20 \mu \mathrm{l}$ acetone. FDA hydrolysis activity was determined after $60 \mathrm{~min}$ incubation at $37^{\circ} \mathrm{C}$, in quadruplicate. After incubation, an aliquote of acetone was added, liquid phase was centrifuged at $4000 \mathrm{rpm}$ and optical density was read at $490 \mathrm{~nm}$.

$$
\text { Fourier transform infrared (FT-IR) }
$$

spectroscopy. FT-IR absorption spectra of potato pulp, grass and their compost extracts - sample water soluble extracts, were recorded on "Vertex 70" with an extension microplate reader HTS-XT ("Bruker", Germany). 10-30 $\mu$ l of each sample were poured out by drops on a 96 place silicon plate, dried at $\mathrm{T}<50^{\circ} \mathrm{C}$, spectra recorded over the wave number range of 4000 $600 \mathrm{~cm}^{-1}$ with 64 scans, resolution of $4 \mathrm{~cm}^{-1}$. Only spectra fitting in the absorption limits between $0.25-0.80$ (where the concentration of a component was proportional to the intensity of the absorption band) were used for data analyses. Data were processed with OPUS 6.5 software. Spectra were vector normalized, baseline corrected by rubber band method, $\mathrm{CO}_{2}$ and $\mathrm{H}_{2} \mathrm{O}$ bands excluded. The absorption band intensities were measured by integration method (integration mode $\mathrm{R}$ - the peak height defined as absorbance value difference between the band maximum and the baseline).

Microbiological testing. Compost water extract ( $8 \mathrm{~g}$ wet compost in $32 \mathrm{ml}$ distilled water) was diluted serially and spread on the defined media for the enumeration of microorganisms. The media and incubation conditions were as follows: tryptone glucose yeast extract agar ("Sifin", Germany) for heterotrophic aerobic bacteria, $30^{\circ} \mathrm{C}$ for two days; Sabouraud agar ("Sifin") for fungi, $30^{\circ} \mathrm{C}$ for three days.

Eco-toxicological evaluation. Seed germination test. The germination test utilized compost water extract. The control was distilled water. Cress (Lepidium sativum L.) and rye (Secale cereale L.) were used as test-organisms. Testing was performed in Petri plates 
containing $10 \mathrm{ml}$ liquid covered by filter paper and 10 seeds, in duplicate. Seeds were incubated in dark at $20^{\circ} \mathrm{C}$ during four days.

Earthworm avoidance test. The test organisms were adults of cultivated earthworm population of breeding line 'Red California hybrid'. Six-section units for testing were designed according to (Roembke, 2008). Two samples were randomly placed in each testing unit (one sample in three sections). Ten worms were placed in the centre of the testing unit; the unit was covered with a lid and left for $72 \mathrm{~h}$ outside, under the tent. Afterwards, compost from each section was tested for the presence of worms.

Statistical analysis. The experiment was performed in duplicate, and each result in figures and tables was the mean of at least three replicated treatments, until otherwise noted. Data presented in figures were expressed as mean \pm standard deviation. Differences between the treatments were evaluated by Student's $t$-test methods $(p<0.05)$.

\section{Results and discussion}

Physico-chemical characterization of raw material and composted substrate. The rate and extent of the transformations of carbon- and nitrogen-containing substrates into more stable organic matter depend on available substrates and the process variables used to control composting (Marche et al., 2003). Physicochemical properties of the substrate to be composted were analyzed before the experiment. Data on the concentration of ash, N, K, P, C and S in two samples were expressed both, per dry and fresh weight. As is shown in Table 1, similar concentrations of $\mathrm{C}, \mathrm{K}$, and $\mathrm{S}$ in potato pulp and grass per dry weight were found. In turn, the concentration of $\mathrm{N}$ in potato pulp was found to be $42 \%$ higher, while $\mathrm{P}$ and ashes $-41 \%$ and $25 \%$ lower, respectively. The theoretical $\mathrm{C}: \mathrm{N}$ ratios of the substrate in three experimental sets were calculated, using the data on $\mathrm{C}$ and $\mathrm{N}$ concentrations per fresh weight (Tables 1-2).

Table 1. Concentration of ash, N, K, P, C and S in potato pulp and grass before composting

\begin{tabular}{ccccccccc}
\hline & & Dry weight & Ash & $\mathrm{N}_{\text {total }}$ & $\mathrm{K}$ & $\mathrm{P}$ & $\mathrm{S}$ & \\
\hline \multirow{2}{*}{ Grass } & \% per dry weight & 71.74 & 7.33 & 1.52 & 1.85 & 0.27 & 48.0 & 0.11 \\
& \% per fresh weight & - & 5.26 & 1.09 & 1.33 & 0.19 & 34.43 & 0.08 \\
\hline \multirow{2}{*}{ Potato pulp } & \% per dry weight & 14.34 & 5.47 & 2.16 & 1.75 & 0.16 & 47.5 \\
& \% per fresh weight & - & 0.78 & 0.31 & 0.25 & 0.12 \\
\hline
\end{tabular}

The $\mathrm{C}: \mathrm{N}$ ratio of potato pulp with grass in proportions $1: 3 ; 1: 1$ and $3: 1$ was $27.16,29.46$ and 30.75 , respectively (Table 2). These data fit in the range of the optimum C:N ratio between 25 and 35 for composting (Golueke, 1992). Differences in the concentration of potato pulp and grass in the composting substrate influenced the overall composting process. In particular, an increase of grass amount stimulated an increase of the temperature in windrows during the thermophilic phase, which corresponds to the peak of degradation of fresh organic matter.

Table 2. Calculated C:N ratio for the experimental sets with potato pulp and grass in different proportions

\begin{tabular}{cccc}
\hline & \multicolumn{3}{c}{ Experimental sets } \\
\cline { 2 - 4 } Parameter & $\begin{array}{c}\mathrm{A} \\
\text { (potato pulp:grass } \\
\text { as 3:1 by weight) }\end{array}$ & $\begin{array}{c}\mathrm{B} \\
\text { (potato pulp:grass } \\
\text { as } 1: 1 \text { by weight) }\end{array}$ & $\begin{array}{c}\mathrm{C} \\
\text { (potato pulp:grass } \\
\text { as 1:3 by weight) }\end{array}$ \\
\hline $\mathrm{C}-$ residual units per fresh weight & 54.86 & 82.48 & 110.10 \\
$\mathrm{~N}-$ residual units per fresh weight & 2.02 & 2.80 & 3.58 \\
C:N & 27.16 & 29.46 & 30.75 \\
\hline
\end{tabular}

The highest temperature at the $5^{\text {th }}$ day of the experiment $\left(45.5 \pm 0.7^{\circ} \mathrm{C}\right.$ ) was detected in set $\mathrm{C}$ (Fig. 1 a). The lowest temperature was detected in the windrows of set A, which contained the highest amount of potato pulp. Such a tendency was shown also for the $10^{\text {th }}$ and $15^{\text {th }}$ day of the experiment (Fig. 1 a). Temperature and oxygen fluctuate in response to microbial activity, which consumes oxygen and generates heat (Gajalakshmi, Abbasi, 2008). Most probably, the highest concentration of grass in set $\mathrm{C}$ among the treatments studied, resulted in higher porosity and, therefore, the better aeration under tested conditions. As windrows were aerated primarily by natural or passive air flow in this experiment, the rate of air exchange depended on the porosity of the windrow.
The changes in $\mathrm{pH}$ and redox potential of the compost water extract in dynamics also indicated the differences of the composting processes in windrows with different proportions of potato pulp and grass. The most variable $\mathrm{pH}$ values during the period from the $5^{\text {th }}$ to the $30^{\text {th }}$ day were detected in the set $\mathrm{C}$, with the maximum $\mathrm{pH}$ at the $10^{\text {th }}$ and $30^{\text {th }}$ days of composting (Fig. $1 \mathrm{~b}$ ). Usually, an initial phase of composting is characterized by a low $\mathrm{pH}$ due to the formation of carbon dioxide and volatile fatty acids. With the subsequent evolution of $\mathrm{CO}_{2}$ and utilization of volatile fatty acids, the $\mathrm{pH}$ begins to rise and may reach values exceeding 8.0 (Sharma et al., 1997; Gajalakshmi, Abbasi, 2008). Redox potential in the sets A, B, and C at the end of the experiment in average was 20,0 and 
$-10 \mathrm{mV}$, respectively (results not shown). The C:N ratio represents very good index of the maturity for organic substances, as it significantly affects the microbiological growth (Gajalakshmi, Abbasi, 2008). Concentration of C and $\mathrm{N}$ in compost samples after 30 days of experiment is shown in Figure $1 \mathrm{c}$. No considerable differences between the tested sets were found. $\mathrm{C}: \mathrm{N}$ ratio for the sets $\mathrm{A}, \mathrm{B}$ and $\mathrm{C}$ varied in the range of $13 \div 17$. The decrease of $\mathrm{C}: \mathrm{N}$ ratio

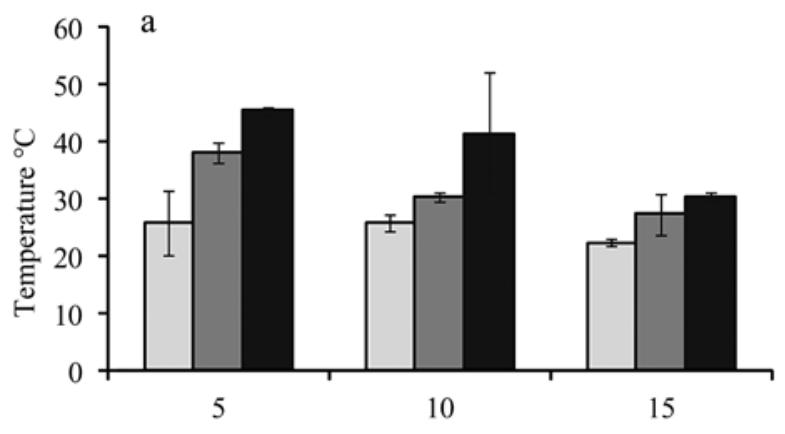

Period of composting, days $\square$ A $\square$ B after 30 days of composting up to $50 \%$ can be attributed to the conversion of organic matter. The addition of materials with a $\mathrm{C}: \mathrm{N}$ ratio below 15 may not alter the microbiological equilibrium of soil. Therefore, the $\mathrm{C}: \mathrm{N}$ ratio below 12 may indicate the suitability for addition into soil (Gajalakshmi, Abbasi, 2008). According to Sharma et al. (1997), the C:N of a good quality compost is within 15-20.

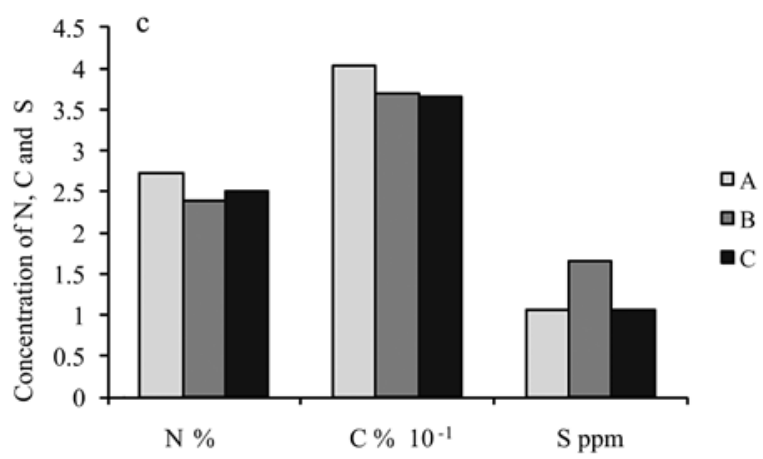

Note. A, B and C - potato pulp and grass were mixed in proportions $3: 1,1: 1$ and 1:3 by weight, respectively; a and b - individual samples were tested, $\mathrm{c}$ - composite samples from A, B and C treatments were tested.

Figure 1. Physico-chemical changes in composting substrate during 30 days of experiment: temperature in windrow (a), $\mathrm{pH}$ value of compost water extracts (b) and concentration of $\mathrm{N}, \mathrm{C}$, and $\mathrm{S}$ in compost samples (c)

Emission of some gaseous products of composting was tested at the $5^{\text {th }}, 10^{\text {th }}$ and $15^{\text {th }}$ day of the experiment. In particular, the highest concentration of $\mathrm{CO}_{2}$ emitted from the windrows, was detected in sets $\mathrm{A}$ and $\mathrm{B}$ at the $5^{\text {th }}$ day of the experiment. Maximum $\mathrm{NH}_{3}$ concentration was found in set $\mathrm{C}$ at the $15^{\text {th }}$ day of the experiment (results not shown). High temperature combined with high exchange rates of the air will increase the loss of ammonia (Vinneras et al., 2003). Figure 1 a shows that the highest temperatures during thermophilic phase were reached in set $\mathrm{C}$.

FT-IR spectroscopy analyses. It is known that determination of the composition of dissolved organic matter is difficult since it is a mixture of lowmolecular weight compounds (free amino acids and sugars) and chemically heterogeneous macromolecules (enzymes, amino-sugar complexes, polyphenols), and humic substances (Chefetz et al., 1998). However, FT-IR spectroscopy is one of methods that have been successfully applied for studies of complex biomixtures,

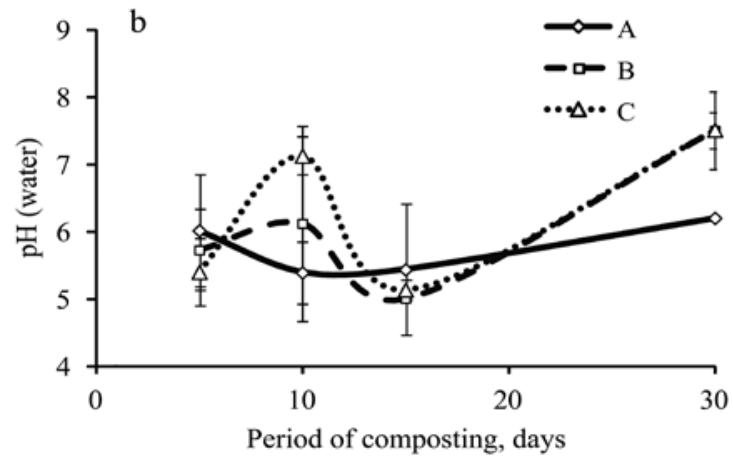

biodegradation and composting of biowastes (Grube et al., 2006). Moreover, this method allows evaluation of the maturity of compost solid fractions as well as characterization of different compost extracts (Chefetz et al., 1998; Carballo et al., 2008). In our study, FT-IR spectroscopy was used for evaluation of water extracts from fresh grass, fresh potato pulp, as well as their compost. FT-IR spectra of grass and potato pulp water extracts look qualitatively similar while the absorption band intensities varied (Fig. 2). Three broad absorption bands with maximums at 1596, 1388 and $1049 \mathrm{~cm}^{-1}$ may be of special interest for evaluation of compost water extracts. Variations of the shape and intensity of these bands indicate differences in the biochemical composition and concentrations of particular compounds. The broad band at the region $900-1100 \mathrm{~cm}^{-1}$ indicates carbohydrates (C-O stretching coupled with $\mathrm{C}-\mathrm{O}$ bending of the $\mathrm{C}-\mathrm{OH}$ groups of carbohydrates including glucose, fructose and glycogen, etc.) (Helm, Naumann, 1995). The spectra of fresh potato pulp extract indicated significantly higher 
content of water soluble polysaccharides $\left(1049 \mathrm{~cm}^{-1}\right)$ than in the grass extract. Moreover, the different profiles of the absorption band in the carbohydrate region (900$1100 \mathrm{~cm}^{-1}$ ) are indicative to the different composition of extracted polysaccharides. The ratio of two intensive bands centered at $1596 \mathrm{~cm}^{-1}(\mathrm{C}=\mathrm{C}$ vibrations of aromatic structures and carboxylate asymmetrical stretching) (SaidPullicino, Gigliotti, 2007) and $1388 \mathrm{~cm}^{-1}$ (C-H bending of $\mathrm{CH}_{3}$ could be assigned to skeleton $\mathrm{C}-\mathrm{H}$ vibrations) may be related to different amino acid composition and can be influenced by high polysaccharide content. Absorption peaks between 2960 and $2850 \mathrm{~cm}^{-1}$ assigned to $\mathrm{C}-\mathrm{H}$ stretch of aliphatic structures, were more pronounced in the potato pulp extract spectra (Carballo et al., 2008). The absorption band centered at $2937 \mathrm{~cm}^{-1}\left(\mathrm{CH}_{3}\right.$ sym stretch) was more intensive in the spectra of potato pulp extract while in the spectra of grass extract a small but well pronounced peak at $830 \mathrm{~cm}^{-1}$ (C-H out-of-plane vibration) of polysaccharides was seen (Ouajai, Shanks, 2005).

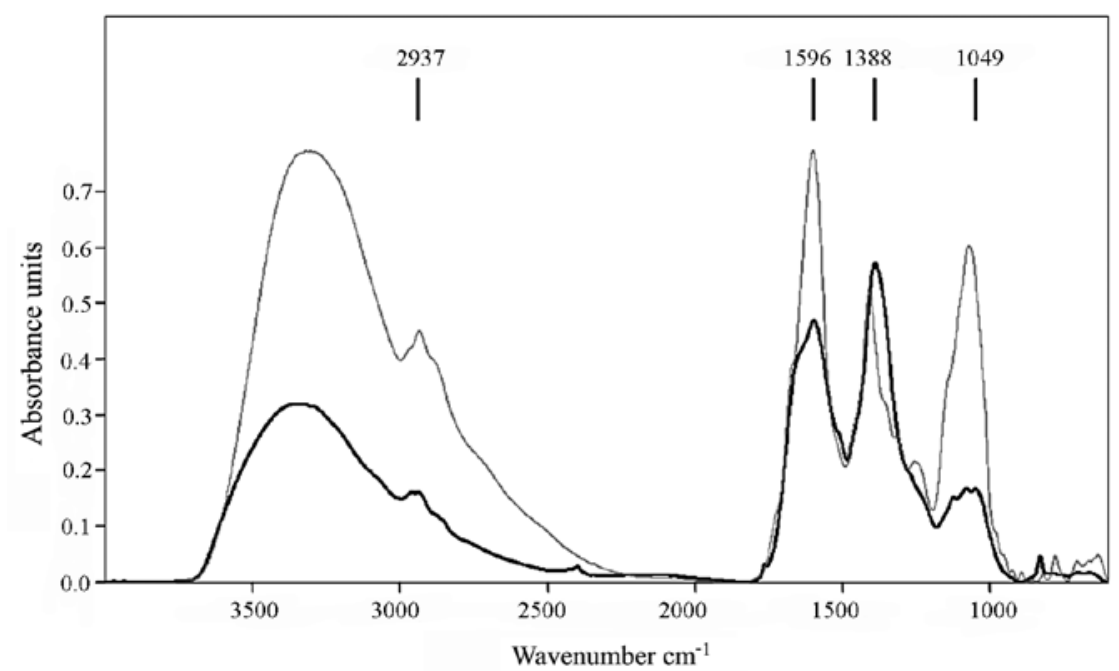

Figure 2. Fourier transform infrared spectra of water extracts of fresh grass $(-)$ ) and fresh potato pulp $\left(-\frac{}{-}\right)$

The spectra profiles of all compost sample water extracts were similar showing two strong absorption bands around $1410 \mathrm{~cm}^{-1}$ (C-O stretching of carbonate) and $1570 \mathrm{~cm}^{-1}(\mathrm{~N}-\mathrm{H}$ in plane bending amide II and secondary amines). Smidt et al. (2005) reported that the increase of amide II band $\left(1570 \mathrm{~cm}^{-1}\right)$ reflects the growth of microbes in compost. The intensities of well pronounced peaks in the carbohydrate region at 1080 and $1050 \mathrm{~cm}^{-1}$ and the peaks between 2960 and $2850 \mathrm{~cm}^{-1}$ (C-H stretch of aliphatic structures) were significantly lower than those of amide II or carbonate (Carballo et al., 2008). Only in the spectra of potato pulp:grass 1:3 and 1:1 after composting for 30 days there was a shoulder at $1667 \mathrm{~cm}^{-1}$ (Fig. 3). In the spectra of compost water extracts this shoulder probably can be assigned to the aromatic $\mathrm{C}=\mathrm{C}$ bonds and $\mathrm{C}=\mathrm{O}$ of amides or carboxylates, and reflects both synthesis and decomposition (Smidt et al., 2005).
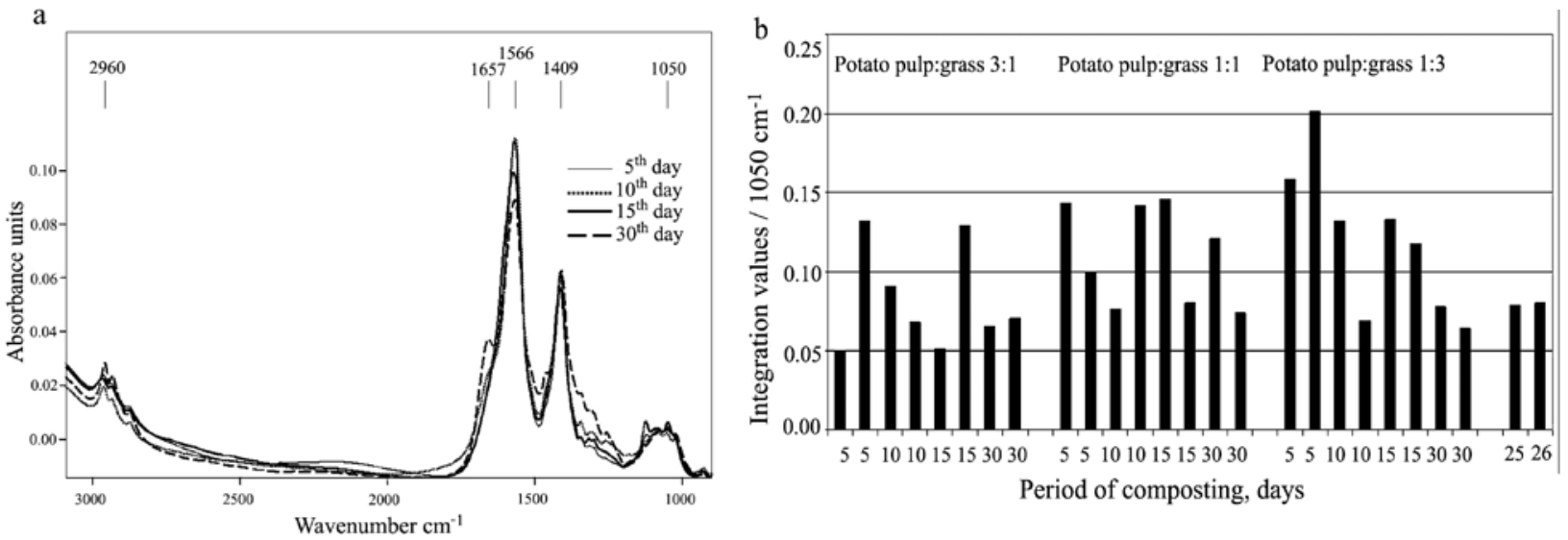

Note. Vector normalized Fourier transform infrared spectra of compost water extracts (a) and the integral values of polysaccharide absorption band intensities in spectra of compost water extracts (b).

Figure 3. Testing results of compost (potato pulp:grass 1:1) water extracts after 30 days of experiment performed by Fourier transform infrared spectroscopy 
Previous studies have shown that the reduction of polysaccharide peak intensity at 1050 $\mathrm{cm}^{-1}$ to a small shoulder in mature compost indicates that during composting mainly polysaccharides have been mineralized (Greve et al., 1993; Chefetz et al., 1998). The integral values of polysaccharide absorption band intensities in spectra of compost water extracts showed that the compost material in windrows was not homogeneous because the data of parallel samples in some cases varied for more than $50 \%$ (Fig. 3). Thus in this experiment FT-IR spectroscopic analysis did not allow evaluating the efficiency of applied composting schemes. Yet from the spectra it can be seen that in water extract samples of potato pulp:grass 1:3 after 5 days of composting the content of polysaccharides was higher than in extracts of potato pulp:grass $1: 1$ and 3:1. FT-IR spectral data analyses also showed that during 30 days of composting the content of polysaccharides decreased more in the samples of potato pulp:grass 1:3 due to the higher water soluble polysaccharide content in the $5^{\text {th }}$ day compost extracts.
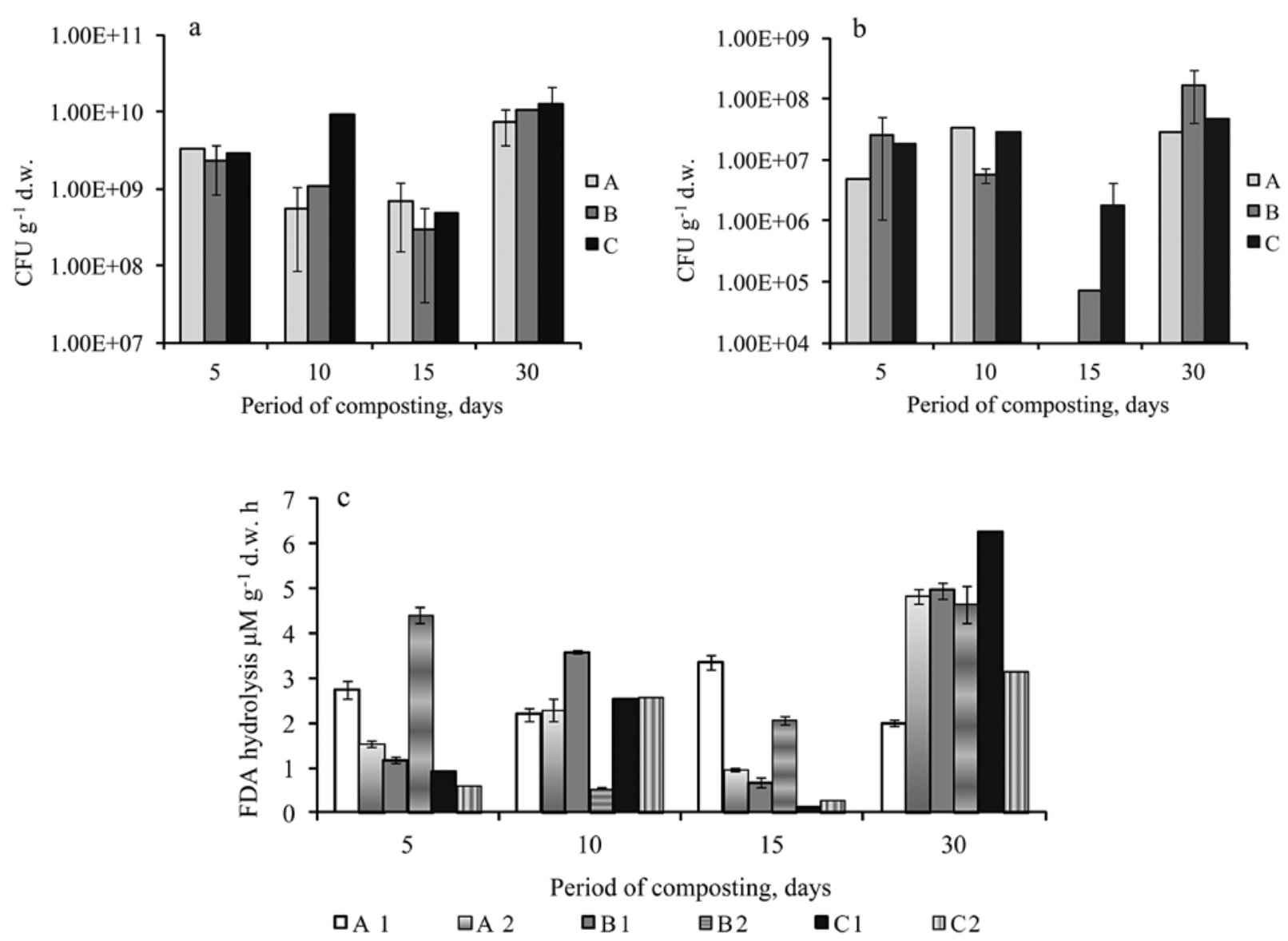

Notes. A, B and C-potato pulp and grass were mixed in proportions $3: 1,1: 1$ and 1:3 by weight, respectively. A1 and A2, B1 and $\mathrm{B} 2, \mathrm{C} 1$ and $\mathrm{C} 2$ are parallel sets.

Figure 4. Changes of microbial activity in compost water extract during 30 days of experiment: number of the total heterotrophic aerobic bacteria (CFU) (a), number of fungi (CFU) (b) and microbial fluorescein diacetate (FDA) hydrolysis activity (c)

substrate during composting. Dynamics of the number of culturable microorganisms in windrows provides additional information on the processes occurring during composting. Comparison of the numbers of heterotrophic aerobic bacteria and microscopic fungi in sets A, B and $\mathrm{C}$ in dynamics did not show any significant differences. An exception was set $\mathrm{C}$ with the highest number of bacteria at the $10^{\text {th }}$ day and the highest number of fungi at the $15^{\text {th }}$ day of the experiment (Fig. $4 \mathrm{a}$ and b). The microbes produce hydrolytic extracellular enzymes to depolymerize complex substances (i.e. plant polymers, cellulose, hemicellulose and lignin) to basic components that are water-soluble (Hankin et al., 1976). The results on microbial enzyme (FDA hydrolysis) activity demonstrated a heterogenity of the samples taken from the parallel sets. On average, there was a tendency of FDA hydrolysis activity to increase at the end of the experiment (Fig. 4 c). 


\section{Effect of moisture on composting process.}

Moisture is one of the composting variables that affect microbial activities, as it provides a medium for the transport of dissolved nutrients required for the metabolic and physiological activities of microorganisms. Moisture content of $60-70 \%$ is generally considered ideal to start with. At later stages of decomposition, the ideal moisture content may be $50-60 \%$. The excess moisture will fill many of the pores between particles, thereby limiting the oxygen transport (Gajalakshmi, Abbasi, 2008). Taking into consideration the experimental conditions, e.g., windrows were made in the field, not covered, climatic conditions influenced the physico-chemical properties of the composting material, particularly, the water content depended on rain, sun or wind. As shown in Figure 5, moisture fluctuations in composting material were negligible during 30 days of experiment and were in the range of $76 \div 87 \%$. An exception was the windrow A1 with a notable decrease of moisture content in dynamics during 30 days, i.e. from $75 \%$ to $59 \%$ (Fig. 5).

In this study, a more detailed comparison of two parallel sets $\mathrm{A} 1$ and $\mathrm{A} 2$ windrows with the ratio potato pulp:grass as $3: 1$, differing in water content, was made. Analysis of the changes in the $\mathrm{pH}$ value and microbiological parameters (enzyme activity and

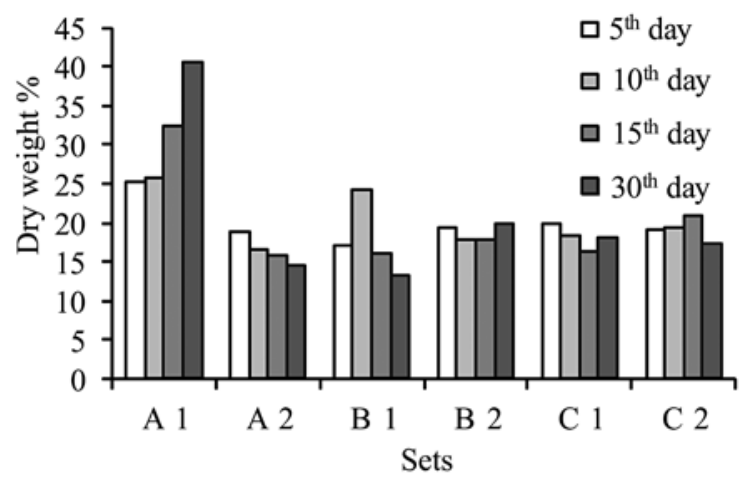

Notes. A, B and C - potato pulp and grass were mixed in proportions $3: 1,1: 1$ and $1: 3$ by weight, respectively. 1 and 2 - parallel sets. A composite sample from each windrow was tested.

Figure 5. Changes of dry matter content in windrows during 30 days of experiment

respiration) indicated the differences of the composting processes in windrows $\mathrm{A} 1$ and A2 with moisture content $59 \div 75 \%$ and $81 \div 86 \%$, respectively (Fig. 6). At the beginning of the experiment, more humid windrow A2 was characterized by lower $\mathrm{pH}$ value, microbial FDA hydrolysis activity and respiration. However, at the $30^{\text {th }}$
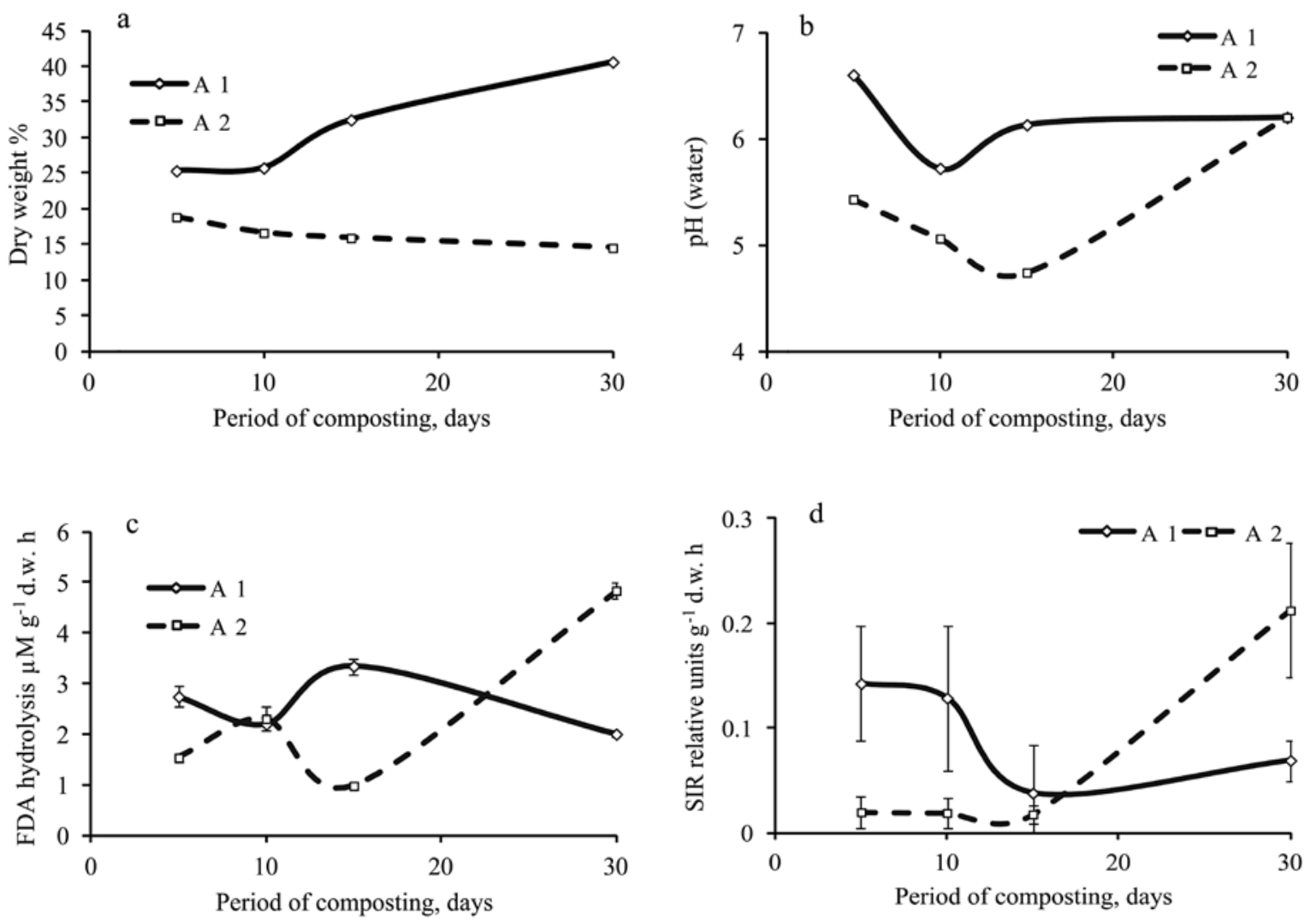

Note. Dry weight (a) and pH value (b), respectively, was measured in composite samples taken from windrows A1 and A2.

Figure 6. Changes of dry matter content (a), pH value (b), microbial fluorescein diacetate (FDA) hydrolysis activity (c), substrate induced respiration (SIR) (d) in the parallel sets A1 and A2 with the ratio potato pulp:grass as 3:1, during 30 days of experiment 
day of the experiment, the $\mathrm{pH}$ value in windrow $\mathrm{A} 2$ was similar to that in windrow A1, microbial enzyme activity and respiration were significantly higher $(F=38.17>$ $F_{0.05}=7.71$ and $F=18.21>F_{0.05}=5.99$, respectively), as compared to those in windrow A1 (Fig. 6).

Compost stability is strongly related to the rate of microbial activity in the compost. The widely used parameter for assessing compost stability is respiration. Oxygen is consumed and carbon dioxide is evolved as a consequence of microbial metabolism. Both of the processes decline at late composting stages (Gajalakshmi, Abbasi, 2008). The results obtained in this study demonstrated that excess of water in set A2 plays a retarding role in a composting process.

Eco-toxicological evaluation of compost samples. The degree of maturity can be revealed by biological methods involving seed germination and by measuring the root length of the ensuing plants. Germination index (a factor of relative seed germination and relative root elongation) values greater than $50 \%$, according to Zucconi et al. (1981), indicate a phytotoxinfree compost.

In this study, the compost, sampled at the $30^{\text {th }}$ day of the experiment, demonstrated the germination index on average not lower than $50 \%$ in six tested windrows. Testing was performed with cress (Lepidium sativum L.) and rye (Secale cereale L.) (results not shown). Earthworm avoidance response is a new tool for rapid and efficient screening of potentially toxic substances added to soil environments (Artuso et al., 2011). Enchytraeids are ecologically relevant soil species and are commonly used in toxicity tests. Their rapid reaction to a chemical exposure can be used as a toxicological measurement endpoint that assesses the avoidance behaviour (Amorim et al., 2008). The results shown in Table 3 summarize behaviour of earthworms during $36 \mathrm{~h}$ incubation in the compost sampled at the end of the experiment. The order of earthworms' preference for compost samples can be listed as follows: $\mathrm{A}<\mathrm{C}<\mathrm{B}$. Therefore, the ratio potato pulp:grass as 1:1 could be considered as the most appropriate under the tested conditions.

Table 3. The results of earthworm avoidance test

\begin{tabular}{ccc}
\hline $\begin{array}{c}\text { Testing unit } \\
\text { No. }\end{array}$ & $\begin{array}{c}\text { Compost samples } \\
\text { in the testing unit }\end{array}$ & $\begin{array}{c}\text { Number of earthworms } \\
\text { per compost sample } \\
\text { (total for three sections) }\end{array}$ \\
\hline 1 & B2 / C1 & $10 / 0$ \\
2 & A1 / C1 & $5 / 5$ \\
3 & A2 / C2 & $2 / 8$ \\
4 & A1 / B1 & $0 / 10$ \\
\hline
\end{tabular}

Note. Compost sampling time - the $30^{\text {th }}$ day, period of incubation $-72 \mathrm{~h}$.

\section{Conclusions}

1. Potato pulp serves as a suitable substrate for composting in combination with grass. The $\mathrm{C}: \mathrm{N}$ ratio of both, potato pulp and grass is near $25 \div 30$, which is considered as optimum for the beginning of the composting process.

2. A decrease of the $\mathrm{C}: \mathrm{N}$ ratio after 30 days of composting in all three experimental sets, differing in the concentration of potato pulp and grass, up to $13 \div 17$ indicates the processes of active conversion of organic matter.

3. Differences in the concentration of potato pulp and grass in the substrate influenced the overall composting. An increase of the grass concentration led to an increase of the temperature in the windrow at the thermophilic phase of the process. This effect can be explained by higher porosity of the composting substrate containing $75 \%$ grass and $25 \%(\mathrm{w} / \mathrm{w})$ potato pulp.

4. Fourier transform infrared (FT-IR) spectra of compost water extracts indicated the heterogenity of compost in windrows.

5. Comparison of data from two windrows with different water content $(59 \div 75 \%$ and $81 \div 86 \%)$ demonstrated considerable differences in dynamics of physico-chemical and microbiological processes. An excess of water in set A2 $(81 \div 86 \%)$ played a retarding role in the composting process. Further field experiment should be performed with controlling the moisture content in windrows.

6. Eco-toxicological testing of compost samples, using germination index and earthworm avoidance test as test criteria, demonstrated appropriate quality of compost samples for being used as soil amendment. The order of earthworms' preference for compost samples can be listed as follows: $\mathrm{A}<\mathrm{C}<\mathrm{B}$. Therefore, the ratio potato pulp:grass as 1:1 could be considered as the most optimal under the tested conditions.

\section{Acknowledgements}

The work was supported by National Research Programme of Latvia (programme No. 2010.10-4/VPP-5 "Sustainable Use of Local Resources (Mineral Deposits, Forests, Food and Transport) - New Products and Technologies"). Authors are grateful to Aloja-Starkelsen Ltd. for providing potato pulp.

Received 06042013

Accepted 09092013

\section{References}

Abe A., Sujaya I.-N., Sone T., Asano K., Oda Y. 2004. Microflora and selected metabolites of potato pulp fermented with an Indonesian Starter Ragi Tapé. Food Technology and Biotechnology, 42 (3): 169-173

Aibibula Y., Okine A., Hanada M., Murata S., Okamoto M., Goto M. 2007. Effect of replacing rolled corn with potato pulp silage in grass silage-based diets on nitrogen utilization by steers. Asian-Australasian Journal of Animal Sciences, 20 (8): 1215-1221

Amorim M. J. B., Novais S., Römbke J., Soares A. M. V. M. 2008. Avoidance test with Enchytraeus albidus (Enchytraeidae): 
effects of different exposure time and soil properties. Environmental Pollution, 155: 112-116

http://dx.doi.org/10.1016/j.envpol.2007.10.028

Artuso N., Kennedy T. F., Connery J., Grant J., Schmidt O. 2011. Assessment of biosolids in earthworm choice tests with different species and soils. Global NEST Journal, 13 (3): $255-265$

Carballo T., Gil M. V., Gomez X., Gonzalez-Andres F., Moran A. 2008. Characterization of different compost extracts using Fourier-transform infrared spectroscopy (FTIR) and thermal analysis. Biodegradation, 19 (6): 815-30 http://dx.doi.org/10.1007/s10532-008-9184-4

Chefetz B., Hadar Y., Chen Y. 1998. Dissolved organic carbon fractions formed during composting of municipal solid waste: properties and significance. Acta Hydrochimica et Hydrobiologica, 26: 172-179 http://dx.doi. org/10.1002/(SICI)1521-401X(199805)26:3<172::AIDAHEH172>3.0.CO;2-5

Chen W., Hoitink H. A. J., Schmitthenner A. F., Tuovinen O. H. 1988. The role of microbial activity in suppression of damping-off caused by Pythium ultimum. Phytopathology, 78 (3): 314-322 http://dx.doi.org/10.1094/Phyto-78-314

Densilin D. M., Srinivasan S., Manju P., Sudha S. 2011. Effect of individual and combined application of biofertilizers, inorganic fertilizer and vermicompost on the biochemical constituents of chilli (Ns-1701). Journal of Biofertilizers and Biopesticides, 2: 106 http://dx.doi.org/10.4172/2155-6202.1000106

Gagnon B., Lalande R., Fahmy S. H. 2001. Organic matter and aggregation in a degraded potato soil as affected by raw and composted pulp residue. Biology and Fertility of Soils, 34 (6): $441-447$

Gajalakshmi S., Abbasi S. A. 2008. Solid waste management by composting: state of the art. Critical Review in Environmental Science and Technology, 38 (5): 311-400 http://dx.doi.org/10.1080/10643380701413633

Golueke C. G. 1992. Bacteriology of composting. Biocycle, 33: $55-57$

Greve B., Haumaier L., Zech, W. 1993. Spectroscopic (IR, NMR) characterization of water-soluble organic substances extracted from straw, straw incubated with Pleurotus ostreatus, and straw compost. Zeitschrift für Pflanzenernährung und Bodenkunde, 156: 103-108 http://dx.doi.org/10.1002/jpln.19931560202

Grube M., Lin J.-G., Lee P.-H., Kokorevicha S. 2006. Evaluation of sewage sludge-based compost by FT-IR spectroscopy. Geoderma, 130 (3-4): 324-333

http://dx.doi.org/10.1016/j.geoderma.2005.02.005

Hankin L. H., Poincelot R. P., Anagnostakis S. L. 1976. Microorganisms from composting leaves: ability to produce extracellular enzymes. Microbial Ecology, 2: 296-308 http://dx.doi.org/10.1007/BF02011649

Helm D., Naumann D. 1995. Identification of some bacterial cell components by FT-IR spectroscopy. FEMS Microbiology Letters, 126: $75-80$ http://dx.doi.org/10.1111/j.1574-6968.1995.tb07393.x

ISO 5983-2:2009. Animal feeding stuffs. Determination of nitrogen content and calculation of crude protein content. Part 2: Block digestion and steam distillation method

ISO 5984:2002/Cor 1:2005. Animal feeding stuffs. Determination of crude ash
ISO 6491:1998. Animal feeding stuffs. Determination of phosphorus content. Spectrometric method

Krzywy E., Woloszyk C., Mazur T., Krzywy J. 2004. Changes in chemical composition during composting of potato pulp with municipal sewage sludge. Zeszyty Problemowe Postepow Nauk Rolniczych, 499: 181-188

Lesiecki M., Białas W., Lewandowicz G. 2012. Enzymatic hydrolysis of potato pulp. Acta Scientiarum Polonorum, Technologia Alimentaria, 11 (1): 53-59

LVS EN ISO 6869:2002 Animal feeding stuffs. Determination of the contents of calcium, copper, iron, magnesium, manganese, potassium, sodium and zinc. Method using atomic absorption spectrometry

Marche T., Schnitzer M., Dinel H., Pare T., Champagne P., Schulten H.-R., Facey G. 2003. Chemical changes during composting of a paper mill sludge-hardwood sawdust mixture. Geoderma, 116 (3-4): 345-356 http://dx.doi.org/10.1016/S0016-7061(03)00108-3

Orrico A. C. A., Centurion S. R., de Farias R. M., Orrico Jr. M. A. P., Garcia R. G. 2012. Effect of different substrates on composting of poultry litter. Revista Brasileira de Zootecnia, 41 (7): 1764-1768 http://dx.doi.org/10.1590/S1516-35982012000700028

Ouajai S., Shanks R. A. 2005. Composition, structure and thermal degradation of hemp cellulose after chemical treatments. Polymer Degradation and Stability, 89: 327-335 http://dx.doi.org/10.1016/j.polymdegradstab.2005.01.016

Roembke J. 2008. Bioavailability in soil: the role of invertebrate behaviour. Chapter 12. Developments in Soil Science, 32: 245-260

Said-Pullicino D., Gigliotti G. 2007. Oxidative biodegradation of dissolved organic matter during composting. Chemosphere, 68 (6): 1030-1040 http://dx.doi.org/10.1016/j.chemosphere.2007.02.012

Sharma V. K., Canditelli M., Fortuna F., Cornacchia G. 1997. Processing of urban and agro-industrial residues by aerobic composting: review. Energy Conversion and Management, 38: $453-478$

http://dx.doi.org/10.1016/S0196-8904(96)00068-4

SmidtE.,EckhardtK.U.,LechnerP., SchultenH. R., Leinweber P. 2005. Characterization of different decomposition stages of biowaste using FT-IR spectroscopy and pyrolysis-field ionization mass spectrometry. Biodegradation, 16 (1): 67-79 http://dx.doi.org/10.1007/s10531-004-0430-8

Vinneras B., Bjorklund A., Jonsson H. 2003. Thermal composting of faecal matter as treatment and possible disinfection method-lab scale and pilot scale studies. Bioresource Technology, 88: 47-54 http://dx.doi.org/10.1016/S0960-8524(02)00268-7

Zucconi F., Pera M. A., Forte M., Bertoldi M. 1981. Evaluating toxicity of immature compost. Biocycle, 22: 54-57 
ISSN 1392-3196 / e-ISSN 2335-8947

Zemdirbyste-Agriculture, vol. 101, No. 1 (2014), p. 57-66

DOI 10.13080/z-a.2014.101.008

\title{
Bulvių išspaudos kaip kompostavimo substrato komponentas
}

\author{
O. Muter ${ }^{1}$, A. Pogulis ${ }^{2}$, M. Grube ${ }^{1}$, M. Gavare ${ }^{1}$, A. Berzins ${ }^{1}$, S. Strikauska ${ }^{3}$, \\ U. Hansons ${ }^{2}$, A. Hansons ${ }^{2}$ \\ ${ }^{1}$ Latvijos universiteto Mikrobiologijos ir biotechnologijos institutas \\ ${ }^{2}$ EKOTRI Ltd. \\ ${ }^{3}$ Latvijos žemès ūkio universitetas
}

\section{Santrauka}

Bulvių išspaudos yra atliekos, kurių didelis kiekis susidaro krakmolo gamybos metu. Jų ịterpimas gerina dirvožemio fizikines ir biochemines savybes. Siekiant palyginti kompostavimo proceso dinamiką per 30 dienų laikotarpį, ekologiškai augintų bulvių išspaudos buvo sumaišytos su ekologiškai augintomis žolemis trimis santykiais 75:25 (A), 50:50 (B) ir 25:75 (C) \% pagal masę (w/w). Minilauko bandymas atliktas naudojant 0,7 $\mathrm{m}^{3}$ komposto krūvas, kurios buvo paliktos neapdengtos ir papildomai nemaišytos kompostavimo metu, išskyrus mėginių paėmimą. Per 30 bandymo dienų C:N santykis sumažèjo nuo $25 \div 30$ iki $13 \div 17$; tai rodo aktyvius organinių medžiagų pokyčius komposto krūvose su ịvairiais substrato komponentų deriniais. Padidinus žolių kiekį, termofilinès kompostavimo fazès metu komposto krūvoje padidejo temperatūra. Tai galima paaiškinti kompostavimo substrato, sudaryto iš 75 $\%$ žolių ir $25 \%$ (pagal masę) bulvių išspaudų, didesniu poringumu. Komposto vandens Fourier transformacijos infraraudonoji (FT-IR) spektroskopija parodè komposto nevienalytiškumą. Drègmès kiekis dviejuose komposto krūvose buvo atitinkamai $59 \div 75$ ir $81 \div 86 \%$; tai rodo didelius fizikiniu bei cheminiu ir mikrobiologiniu procesu dinamikos skirtumus. Pagal sliekų pirmenybès teikimą kompostams ėminiai pasiskirstė taip: $\mathrm{A}<\mathrm{C}<\mathrm{B}$, todėl bulvių išspaudų ir žolių santykị 1:1 galima laikyti optimaliu tirtomis sąlygomis.

Reikšminiai žodžiai: bulvių išspaudos, ekotoksiškumas, fermentų mikrobinè veikla, Fourier transformacijos infraraudonoji spektroskopija, kompostavimas, sliekų vengimo testas. 